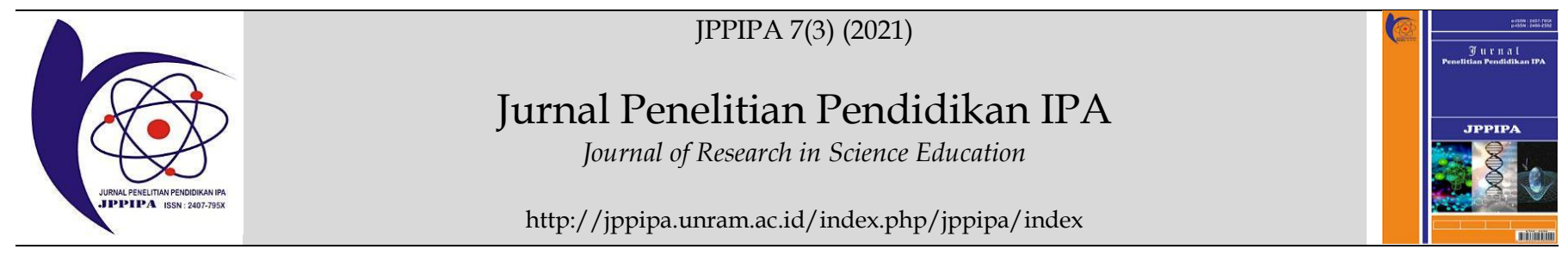

\title{
Impact of Contextual Teaching Learning Model to Science Process Skills and Scientific Attitudes of Students
}

\author{
Kadmayana1, A.Halim 2*, Mustafa², S. Ilyas ${ }^{3}$ \\ 1. Department of Science Education, Graduate School, Universitas Syiah Kuala, Banda Aceh, Indonesia 23111 \\ ${ }^{2}$ Department of Physics Education, Faculty of Teacher and Educational, Universitas Syiah Kuala, Banda Aceh, Indonesia 23111 \\ ${ }^{3}$ Department of Physics, Faculty of Science and Mathematics, Universitas Syiah Kuala, Banda Aceh, Indonesia 23111
}

\section{DOI: $10.29303 /$ jppipa.v7i3.714}

\section{Article Info}

Received: April 19th 2021

Revised: June 17th 2021

Accepted: June $21^{\text {th }}, 2021$

\begin{abstract}
Science process skills (SPS) are skills that need to be developed in students in learning science such as science. The low level of SPS on the science concept is influenced by the learning model which emphasizes the aspects of receiving full information from the teacher. Student SPS is also dominated by an increase in scientific attitudes that require students to show their sensitivity to the surrounding environment. This study aims to determine science process skills and increase students' scientific attitudes through the implementation of the contextual teaching and learning model at MTsS Muta'allimin Aceh Besar. The method used in this study was an experiment with a one-group pretest-posttest design. The instruments used were observation sheets and questionnaires. The results showed that the implementation of the CTL learning model could improve students' SPS in both categories with an average score of 71-85 and very good categories with an average score of 86. In addition to improving the SPS learning model implementation, CTL can also improve students' scientific attitudes with a value $N$-gain average of 0.63 including the moderate category. The results of the improvement obtained by the average student are in good categories with an average score of 71-85 then the category is very good with an average score, 86-100. The conclusion in this study proves that the CTL model can improve student learning skills and scientific attitudes, especially the material of vibration, waves, and sound.
\end{abstract}

Keywords: Contextual teaching, learning, Science, Process Skills, Scientific Attitudes

Citation: Kadmayana, K., Halim, A., Mustafa, M., \& Ilyas, S. (2021). Impact of Contextual Teaching Learning Model to Science Process Skills and Scientific Attitudes of Students. Jurnal Penelitian Pendidikan IPA, 7(3), 375-380. doi:https://doi.org/10.29303/jppipa.v7i3.714

\section{Introduction}

Learning science is one of the lessons that contain science in it. Science is the study of natural phenomena in the form of facts, concepts, and laws that have been verified through a series of studies. Science learning is expected to help students understand natural phenomena (Fitriyati et al., 2017). To improve students' understanding of science lessons, it is necessary to have a student-centered learning model, so that it can increase their understanding. One of the student-centered learning models in the form of contextual teachinglearning (CTL) learning model, where this model is able to involve students in learning activities directly. Handini et al (2016) said that the CTL learning model can be applied in learning, especially in science learning. CTL is a learning model that emphasizes the full process of children's involvement to find the material being studied and relate it to real-life situations (Fua et al., 2017). CTL learning involves students in important activities that help students relate academic 
learning to the real-life contexts they face (Rahmawati, 2018).

The results of preliminary review through observation and interviews at MTsS Muta'allimin show that science learning activities so far have been more centered on teachers than students. This phenomenon is in contrast to the learning development process in the 21st century and the 2013 curriculum-based learning which requires students to take an active role in learning activities. The results of the review also prove that students' science process skills have not as a whole understood well, because students are not able to instill a scientific attitude towards the material or concept they are learning.

The results of the National Examination (UN) review in the last three years at MTsS Muta'allimin also proved that the average score of the National Examination in Science subjects was in the poor category. The results of the National Examination of Science Lessons in the 2016/2017 school year obtained an average value of 37.57 (Puspendik, 2017). The results of the IPA UN in the 2017/2018 school year obtained an average of 43.76 (Puspendik, 2018). The results of the physics National Examination in the 2018/2019 academic year are 38.58 (Puspendik, 2019). The average National Examination result of students in science lessons is in the poor category because there are still some students who do not understand the concepts or science materials well. The low level of SPS on the concept of science (physics) is influenced by the learning model which emphasizes the aspects of receiving full information from the teacher (Salamah \& Mursal, 2017).

The low level of SPS and the scientific attitude of these students show that the CTL model is appropriate. Rinsiyah's research results (2016); show that the CTL model that he developed through the learning module was able to improve student SPS and scientific attitudes better than before. Marnita (2013); and Apriani et al (2017) say that contextual learning can also be a basis for building students' cognitive, affective, and psychomotor abilities, where these three elements are contained in the aspects of SPS, namely observing, classifying, measuring, interpreting, predicting, implementing, planning research, and communicating. Besides, science process skills can also be improved by using group investigation learning (Sholihah et al, 2016), Process Oriented Guided Inquiry Learning (POGIL) (Ramdani and Sadijani, 2017), ICARE learning model (Mahdian et al, 2019), critical thinking skills (Pradana and Suprapto, 2020), guided inquiry and problem-based learning models (Halim et al, 2021a), concept attainment models (Halim et al, 2021b), and student worksheets with PhET
(Arifullah et al, 2020). Science process skills are one of the aspects of higher-order thinking skills (Halim et al, 2018).

The CTL learning model allows students to associate the content of academic subjects with the context of everyday life (Muhsan \& Letasado, 2020). The CTL model emphasizes the activeness of students in learning the material. In the process, learning is carried out actively, creatively, productively, through collaboration, direct student experience, application concepts, and in pleasant situations (Maghfiroh \& Julianto, 2014). This proves that through the CTL model, SPS and students' scientific attitudes will be realized in students. Besides, Contextual Teaching can also improve Quality Tests (Desnita et al, 2021).

\section{Method}

\section{Research Design}

The method used in this research is an experimental method in the form of pre-experimental with one group pretest-posttest design. In this research method, the researcher only uses one class for research as an experimental class. The design of this research can be seen in Table 1.

Table 1. Research Design

\begin{tabular}{llll}
\hline Class & Pretest & Treatment & Posttest \\
\hline Eksperiment & $\mathrm{O}_{1}$ & $\mathrm{X}$ & $\mathrm{O}_{2}$ \\
\hline & & \multicolumn{3}{c}{ Sugiyono, (2018) }
\end{tabular}

\section{Population and Sample}

The population in this study were all students of class VIII MTsS Muta'allimin Aceh Besar, totaling 256 students from 8 classes. Which consists of 4 classes for men and 4 classes for women. The technique of determining the research sample using the purposive sampling technique (certain considerations). Sampling was carried out based on the consideration of the physics teacher concerned on the basis of the low average student learning outcomes in science lessons or did not meet the Minimum Completion Criteria. The sample in this study were students of class $\mathrm{VIII}_{\mathrm{E}}$, amounting to 30 students.

\section{Data Collection}

The instruments used in this study were an observation sheet and a questionnaire to determine the student's scientific process knowledge and attitude. The SPS indicator in this study was adopted by Diana and Lestari (2018), while the scientific attitudes of students are adjusted to the indicators put forward by Ulva, et al. 
(2017). The data collection procedure was carried out by distributing a scientific attitude questionnaire at the time of the pretest to determine the students' initial scientific attitude before applying the CTL learning model, during the learning process through the CTL model, it could be seen from the student's SPS, then the final stage was distributing a scientific attitude questionnaire in the posttest.

\section{Data Analysis}

The data analysis technique in this study used an observation sheet to measure students' SPS who were analyzed using the percentage equation. Then to find out the increase in students' scientific attitudes using a questionnaire using the $\mathrm{N}$-gain equation.

\section{Result and Discussion}

Science process skills are the ability of students to carry out a process of seeking scientific knowledge so that it is through scientific investigation. Maison et al (2019) said that process skills are also shown in 21stcentury education, where through practicum activities students can analyze and evaluate so that students can think critically. Science process skills are measured when students carry out practical activities in accordance with the steps contained in the Student Worksheet. Five observers observed scientific process skills during practicum activities. The results of the analysis of students' science process skills can be seen in Table 2.

Table 2. Students SPS Analysis Results

\begin{tabular}{|c|c|c|c|}
\hline No & Indicator & $\begin{array}{l}\text { Percentage } \\
(\%)\end{array}$ & Category \\
\hline 1 & Observing & 85.4 & Good \\
\hline 2 & Grouping/Classifying & 87.2 & Very good \\
\hline 3 & Interpreting & 90.8 & Very good \\
\hline 4 & Predicting & 85.4 & \\
\hline 5 & Doing Communication & 94.6 & Very good \\
\hline 6 & Asking Questions & 85.0 & Good \\
\hline 7 & Asking Hypotheses & 84.2 & Good \\
\hline 8 & $\begin{array}{l}\text { Planning experiments } \\
\text { or investigations }\end{array}$ & 99.2 & Very good \\
\hline 9 & $\begin{array}{l}\text { Using tools, material or } \\
\text { sources }\end{array}$ & 97.1 & Very good \\
\hline 10 & Applying concepts & 97.5 & Very good \\
\hline 11 & $\begin{array}{l}\text { Conduct an experiment } \\
\text { or investigation }\end{array}$ & 92.5 & Very good \\
\hline
\end{tabular}

Based on the results of the analysis of the eleven SPS indicators in Table 2, it proves that the CTL learning model can create a meaningful learning atmosphere because this CTL model requires students to find their own knowledge and strengthen the concept directly through practicum activities. The results of this study are in accordance with what was stated by Wardana et al (2013) that science process skills in learning include (making observations, determining variables, making hypotheses, measuring, and analyzing data, drawing conclusions, and making reports on practicum results) will be accessible. by applying a contextual learning model. The results of research by Neftyan et al (2018) also prove that the CTL model is able to attract and make students actively involved in the learning process.

Through this CTL learning model, it can also improve students' scientific attitudes. The scientific attitude is the tendency, readiness, or willingness of students to respond or behave scientifically. A scientific attitude can also be interpreted as an attitude that is embedded in students a persistence or seeking scientific knowledge by instilling curiosity, being honest, careful, conscientious, responsible, caring for the environment, cooperating, receiving information, responding to information, and assessing information.

According to Sakin (2020) scientific attitudes are curious thoughts and behaviors that facilitate problemsolving, produce science, and in short, transfer research and technical competencies into practice. The scientific attitude of students was obtained from the results of the analysis of the questionnaires distributed in the pretest and posttest. The results of the average analysis of students' scientific attitudes before and after applying the CTL learning model can be seen in Figure 1.

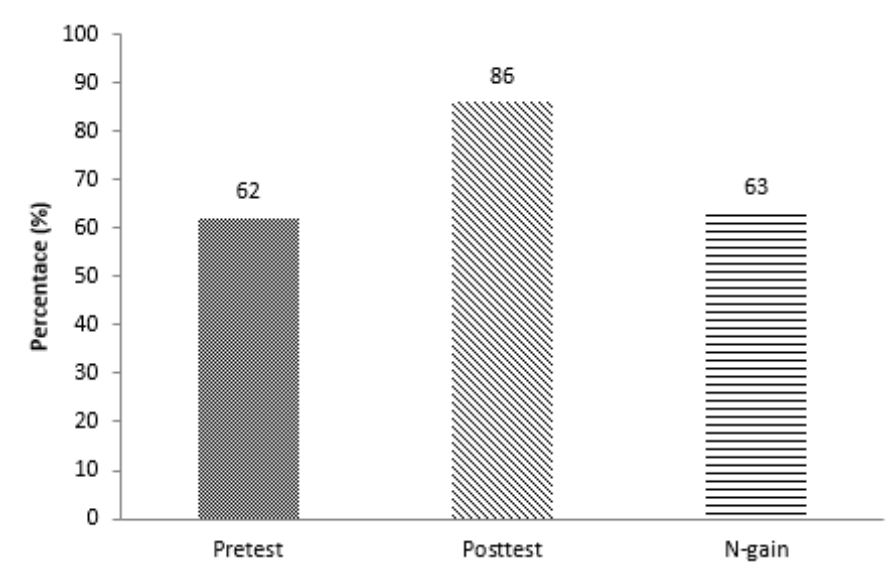

Figure 1. Average Results of Scientific Attitudes

Figure 1 shows the results of the analysis of students' scientific attitudes before and after applying the CTL learning model. The results of the scientific attitude analysis pretest obtained an average of 62 and a posttest of 86 . Based on the results obtained, it proves that 
the CTL learning model can improve students' scientific attitudes. The results of the analysis are $\mathrm{N}$-gain included in the medium category with an average score of 63 . This is in accordance with the research conducted by Adi et al (2019) which states that contextual models can improve students' scientific attitudes because scientific attitudes are an attitude that must be possessed. by students who study science, especially physics, where students are required to show their sensitivity to the surrounding environment.

To find out the increase in the scientific attitude of indicator students before and after applying the CTL learning model can be seen in Figure 2. Figure 2 shows the results of the scientific attitude analysis of indicator students before and after applying the CTL learning model. Based on the results of data analysis, it proves that the average student after applying the learning model is included in the good and very good criteria. This proves that the CTL learning model can improve students' scientific attitudes towards science (physics) learning on vibrations, waves, and sound. Suryawati \& Usman (2018) said that a scientific attitude is a prerequisite and behavior that is needed to be practiced by the science community.

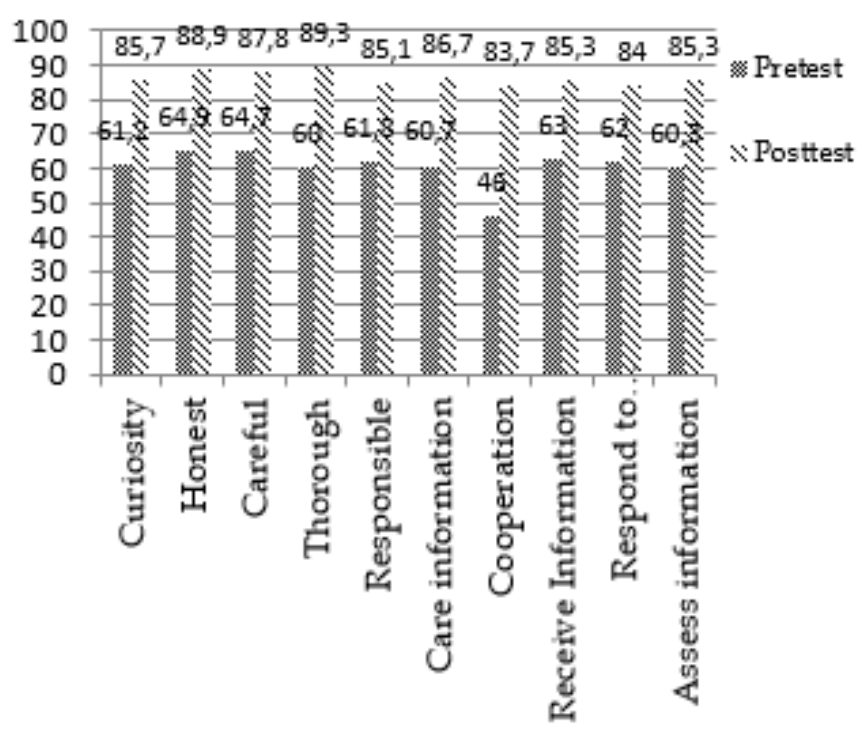

Figure 2. Average Result of Student's Scientific Attitude

Rinsiyah (2016) said that through this CTL model students can improve scientific attitudes because CTL can actively involve students in building knowledge and developing their skills.

Table 3 shows that the results of the scientific attitude analysis of indicators obtained by the average student before applying the CTL learning model were sufficient criteria, but after applying the CTL learning model it was considered good and very good. This proves that the CTL learning model is able to improve scientific attitudes on each indicator.

To clarify the results of the indicator criteria, it can be seen in Table 3 .

Table 3. Result of Analysis of N-gain Perindikator

\begin{tabular}{clll}
\hline No & Indicator & N-gain & Kategori \\
\hline 1 & Curiosity & 0.63 & Average \\
2 & Honest & 0.68 & Average \\
3 & Careful & 0.65 & Medium \\
4 & Thorough & 0.73 & High \\
5 & Responsible & 0.61 & Average \\
6 & Care of the environment & 0.66 & Moderate \\
7 & Cooperation & 0.70 & Moderate \\
8 & Receiving information & 0.60 & Moderate \\
9 & Responding to information & 0.58 & Moderate \\
10 & Assessing information & 0.63 & Moderate \\
\hline
\end{tabular}

This is in accordance with research conducted by Hindasah (2010); and Rahmawati (2018) also proved that the CTL learning process can increase curiosity and gain high student knowledge when educators explain the material, indicating that there is an impetus for learning needs and aspirations in the future and in the context of acquiring knowledge, because students become bolder, and actively ask questions, actively express opinions and students actively cooperate in group activities.

\section{Conclusion}

The implementation of the CTL learning model shows that the average student's science process skills are in the good and very good categories. The results obtained on the indicators of observing, predicting, asking questions, and proposing hypotheses obtained an average score of 71-85. Then the indicators of grouping, interpreting, communicating, planning experiments or investigations, using tools, materials, or sources, applying concepts, and conducting experiments or investigations obtained an average score of 86 . The implementation of the CTL learning model can also improve students' scientific attitudes with grades. The $N$ gain average of 0.63 is in the moderate category. The results per indicator obtained by the average student are in the good and very good categories. The results of the analysis on indicators of curiosity, cooperation, receiving information, responding to information, and assessing information obtained an average score of 7185. Then on the indicators of being honest, careful, thorough, and caring for the environment, an average score of 86-100. 


\section{Acknowledgements}

Thanks to the leaders and teaching staff at MTSs Muta'allimin who have provided service facilities during the research and thanks to the supervisor who has guided in completing this article.

\section{References}

Adi, P.N., Yulianto, A.R., \& Zaini, M. (2019). Menumbuhkan Sikap Ilmiah (Kolaborasi, Keterbukaan Diri, dan Tanggung Jawab) Melaui Pembelajaran Kontekstual. Spektra: Jurnal Kajian Pendidikan Sains, 5(2):140-149. doi: http://dx.doi.org/10.32699/spektra.v5i2.98 [Indonesian]

Apriani, S., Sudin, A., \& Panjaitan, LR. (2017). Penerapan Contextual Teaching and Learning (CTL) untuk Meningkatkan Keterampilan Proses Sains pada Materi Perubahan Sifat Benda. Jurnal Pena Ilmiah, 2(1):401-410. doi: https://doi.org/10.17509/jpi.v2i1.10675 [Indonesian]

Arifullah, Halim, A., Syukri, M., \& Nurfadilla, E. (2020). The development of student worksheets with PhET assisted to improve student science process skill. Journal of Physics: Conference Series, 1460, $12144 . \quad$ https://doi.org/10.1088/17426596/1460/1/012144.

Desnita, D., Putra, A., Hamida, S., Marsa, P. B., \& Novisya, D. (2021). Quality Test of Student Worksheets Based on Contextual Teaching And Learning for Class XI High School Physics. Jurnal Penelitian Pendidikan IPA, 7(1), 92-101.

Fitriyati, I., Hidayat, A., \& Munzil. (2017). Pengembangan Perangkat Pembelajaran IPA untuk Meningkatkan Kemampuan Berpikir Tingkat Tinggi dan Penalaran Ilmiah Siswa Sekolah Menengah Pertama. Jurnal Pembelajaran Sains,1(1):27-34. doi: http://dx.doi.org/10.17977/um033v1i1p27-34

Fua, L.J., Lukman, A.A., \& Aripin. (2017). Meningkatkan Hasil Belajar IPA Melalui Model Pembelajaran Contextual Teaching Learning pada Siswa Kelas IV SD Megeri Tabanggele, Kecamatan Anggalomoare, Kabupaten Konawe. Jurnal AlTa'dib, 10(2):37-54. doi: http://dx.doi.org/10.31332/atdb.v10i2.623 [Indonesian]

Halim, A., Ayunda, D. S., Susanna, Mustafa, Syukri, M., \& Irwandi. (2021). Development and validation of students' achievement, ability to ask and inductive thinking instruments in the static fluid course. Journal of Physics: Conference Series, 1806(1), $12023 . \quad$ https://doi.org/10.1088/17426596/1806/1/012023.

Halim, A., Elmi, Elisa, Susanna, Khaldun, I., \& Irwandi. (2021). Impact of guided inquiry and problem based learning models on science process skills. AIP Conference Proceedings, 2320(1), 20004. https://doi.org/10.1063/5.0037654.

Halim, A., Farada, S., Hamid, A., Mustafa, Nurulwati, Mahzum, E., \& Irwandi, I. (2021). Effect of concept attainment model on student's science process skills. Journal of Physics: Conference Series, 1882(1), 12157. https://doi.org/10.1088/17426596/1882/1/012157

Halim, A., Ngadimin, Soewarno, Sabaruddin, \& Susanna. (2018). Improvement of High Order Thinking Skill of Physics Student To Prepare Human Resources In Order To Faced of Global Competition In ASEAN Economic Community. Journal of Physics: Conference Series, 1116, 32009. https://doi.org/10.1088/17426596/1116/3/032009.

Handini, D., Gusrayani, D., \& Panjaitan, R. (2016). Penerapan Model Contextual Teaching and Learning Meningkatkan Hasil Belajar Siswa Kelas IV Pada Materi Gaya. Jurnal Pena Ilmiah, 1(1), 451460. doi:https://doi.org/10.23819/pi.v1i1.2974. [Indonesian]

Hindasah, I. (2010). Penerapan Pendekatan Kontekstual untuk Meningkatkan Sikap Ilmiah Siswa pada Pembelajaran Gaya di Kelas V Sekolah Dasar. Eduhumaniora Jurnal Pendidikan Dasar, 2(2):1-12. doi: $\quad$ https://doi.org/10.17509/eh.v2i2.2762 [Indonesian]

Lestari, Y.M., \& Diana, N. (2018). Keterampilan Proses Sains (KPS) pada Pelaksanaan Praktikum Fisika Dasar I. Indonesian Journal of Science Mathematics Education, 1(1):49-54. doi: https://doi.org/10.24042/ijsme.v1i1.2474 [Indonesian]

Maghfiroh, L., \& Julianto. (2014). Penerapan Model Pembelajaran CTL untuk Meningkatkan Hasil Belajar Siswa Pada Mata Pelajaran IPA Kelas V Sekolah Dasar. Jurnal JPGSD, 2(2):1-11. Retrieved from: https://jurnalmahasiswa.unesa.ac.id/index.php Ljurnal-penelitian-pgsd/article/view/10618 [Indonesian]

Mahdian, M., Almubarak, A., \& Hikmah, N. (2019). Implementasi model pembelajaran ICARE 
(Introduction-Connect-Apply-Reflect-Extend) terhadap keterampilan proses sains pada materi larutan elektrolit dan non elektrolit. Jurnal Penelitian Pendidikan IPA, 5(1). doi: https://doi.org/10.29303/jppipa.v5i1.184

Maison, M., Darmaji, D., Kurniawan, D., Astalini, A., Dewi, U., \& Kartina, L. (2019). Analysis of science process skills in physics education students. Jurnal Penelitian dan Evaluasi Pendidikan, 23(2), 197-205. doi:https://doi.org/10.21831/pep.v23i2.28123.

Marnita. (2013). Peningkatan Keterampilan Proses Sains Melalui Pembelajaran Kontekstual pada Mahasiswa Semester 1 Materi Dinamika. Jurnal Pendidikan Fisika Indonesia, 9(1):43-52.

doi: https://doi.org/10.15294/jpfi.v9i1.2579 [Indonesian]

Muhsan, J., \& Letasado, R.M. 2020. Improving Students' Science Process Skills for Material of Forces Through the Contextual Teaching Learning Model (CTL) in Elementary School. Proceeding of the $5^{\text {th }}$ Progressive and Fun Education International Conference (PFEIC 2020), 479:8487.

Retrieved from https://www.atlantispress.com/ proceedings/pfeic-20/125945133.

Neftyan, C., Suyanto, E., \& Suyatna, A. (2018). The Influence of Learning using Contextual Teaching and Learning Approach to Physics Learning outcomes of High School Students. International Journal of Advanced Engineering, Management and Science, $4, \quad 446-450$. https://doi.org/10.22161/ijaems.4.63

Pradana, D., Nur, M., \& Suprapto, N. (2020). Improving Critical Thinking Skill of Junior High School Students through Science Process Skills Based Learning. Jurnal Penelitian Pendidikan IPA, 6(2), 166-172.

doi: https://doi.org/10.29303/jppipa.v6i2.428

Puspendik. (2016). Hasil UN IPA SMP tahun 2017-2019. Balitbang Kemendikbud,https://hasilun.puspen dik.kemdikbud.go.id/\#20162017!smp!capaian_na sional!99\&99\&999!T\&T\&T\&T\&1\&!1!\&, retrieved January 5, 2021. [Indonesian]

Rahmawati, T. (2018). Penerapan Model Pembelajaran CTL untuk Meningkatkan Hasil Belajar Siswa Sekolah Dasar pada Mata Pelajaran IPA. Jurnal Imiah Pendidikan dan Pembelajaran, 2(1). doi:http://dx.doi.org/10.23887/jipp.v2i1.13765. [Indonesian]

Ramdani, A., \& Sedijani, P. (2017). Pengaruh Model Pembelajaran Process Oriented Guided Inquiry Learning (POGIL) Terhadap Pemahaman Konsep IPA, Keterampilan Proses Sains dan Kemampuan
Berpikir Kritis Siswa SMP Negeri 3 Pringgabaya Lombok Timur. Jurnal Penelitian Pendidikan IPA, 3(2). doi: https://doi.org/10.29303/jppipa.v3i2.90 [Indonesian]

Rinsiyah, L. (2016). Pengembangan Modul Fisika Berbasis CTL untuk Meningkatkan KPS dan Sikap Ilmiah Siswa Madrasah Aliyah. Jurnal Pendidikan Matematikan dan Sains, 4(2):152-162. Rinsiyah, I. (2016). Pengembangan modul fisika berbasis CTL untuk meningkatkan KPS dan sikap ilmiah siswa Madrasah Aliyah. Jurnal Pendidikan Matematika dan Sains, 4(2), 152-162. doi:https://doi.org/10.21831/jpms.v4i2.12979 [Indonesian]

Sakin, A. (2020). Preschool Pre-Service Teachers' Scientific Attitudes for Sustainable Professional Development. International Journal of Curriculum and Instruction, 12:1633. Retrieved from https://e ric.ed.gov $/$ ? id=EJ1245118.

Salamah, U., \& Mursal. (2017). Meningkatkan Keterampilan Proses Sains Peserta Didik Menggunakan Metode Eksperimen Berbasis Inkuiri pada Materi Kalor. Jurnal Pendidikan Sains Indonesia. 5(1):59-65. Retrieved from http://jurnal.unsyiah.ac.id/JPSI/article/view/8 $\underline{408}$ [Indonesian]

Solihah, R., Purwoko, A. A., \& Gunawan, E. R. (2016). Penerapan pembelajaran investigasi kelompok untuk meningkatkan keterampilan proses sains ditinjau dari intelligence quotient siswa. Jurnal Penelitian Pendidikan IPA, 2(2). doi: https://doi.org/10.29303/jppipa.v2i2.39 [Indonesian]

Sugiyono. (2018). Metode penelitian Kuantitatif Kualitatif dan RED. Bandung: Alfabeta. [Indonesian]

Suryawati, E., \& Osman, K. (2018). Contextual Learning: Innovative Approach towards the Development of Students' Scientific Attitude and Natural Science Performance. Eurasia Journal of Mathematics, Science and Technology Education, 14(1), 61-76. https://doi.org/10.12973/ejmste/79329.

Wardana, K.I., Marhaeni, N.I.A.A., \& Tika, N.I. (2013). Pengaruh Model Kontekstual terhadap Keterampilan Proses Sains dan Hasil Belajar Sains pada Siswa Kelas IV SD Gugus V Dr. Soetomo. eJournal Program Pascasarjana Universitas Pendidikan Ganesha Program Studi Pendidikan Dasar, 3(1). [Indonesian] 